\title{
Beradaptasi dengan Bencana: Strategi Beribadah Umat Islam dan Kristen di Tengah Pandemi Covid-19
}

\author{
Hasse Jubba* \\ Universitas Muhammadiyah Yogyakarta, Indonesia; hasse@umy.ac.id \\ * Correspondence
}

Received: 2021-01-28; Accepted: 2021-03-08; Published: 2021-04-08.

\begin{abstract}
The Covid-19 pandemic has changed the worship pattern of religious people widely. Religious practices conducted regularly and carried out in special places have shifted. Communal worship practices that involve many worshippers are limited at home and involve limited people. This article aims to explain the form of a strategy of Muslims and Christians in carrying out their worship routines during the covid-19 pandemic. The data used as the basis for analysis are obtained through observations, interviews, and literature studies. This article shows that the change in the pattern of worship is the result of a state of emergency and the choice to continue to carry out obligations as a devoutly religious person. The limitations of the prayer room are circumvented by adjusting it to government policies. Policies on social distancing and compliance with health protocols are efforts to prevent the spread of the virus. In a religious context, it is part of an effort to save lives that must be obeyed. This article is still limited to discussions about changing the pattern of worship practices in two religious groups so it still needs further studies that also look at practices for adherents of other religions.
\end{abstract}

Keywords: Covid-19 pandemic; Islam-Christian; obedience; religious strategy; state policy.

Abstrak: Pandemi Covid-19 telah mengubah pola beribadah umat beragama secara luas. Praktik beragama yang dilakukan secara rutin dan dilaksanakan pada tempat-tempat khusus mengalami pergeseran. Praktik ibadah komunal yang melibatkan banyak jamaah dilakukan terbatas di rumah dengan melibatkan orang yang juga terbatas. Artikel ini bertujuan untuk menjelaskan bentuk strategi umat Islam dan Kristen dalam menjalankan rutinitas ibadahnya di tengah pandemi covid-19. Data yang dijadikan landasan analisis diperoleh melalui observasi, wawancara, dan studi kepustakaan. Artikel ini menunjukkan bahwa perubahan pola ibadah merupakan dampak dari kondisi darurat dan pilihan untuk tetap menjalankan kewajiban sebagai pemeluk agama yang taat. Keterbatasan ruang beribadah disiasati dengan menyesuaikannya dengan kebijakan pemerintah. Kebijakan mengenai social distancing dan kepatuhan terhadap protokol kesehatan merupakan ikhtiar untuk mencegah penyebaran virus. Dalam konteks beragama, ini merupakan bagian dari upaya menyelamatkan jiwa sehingga ia harus dipatuhi. Artikel ini masih terbatas pada diskusi mengenai perubahan pola praktik beribadah pada dua kelompok agama sehingga masih perlu dilengkapi dengan kajian yang juga melihat praktik bagi pemeluk agama-agama lain.

Kata Kunci: Islam-Kristen; kebijakan negara; kepatuhan; pandemi covid-19; strategi beragama.

\section{Pendahuluan}

Pandemi Covid-19 yang telah memasuki tahun kedua, berdampak signifikan terhadap perubahan pola beribadah umat Islam dan Kristen di Indonesia (Indriya, 2020; Wibisono, Truna, \& Rahman, 2021). Praktik ibadah dilakukan dengan adaptasi-adaptasi dalam banyak hal, termasuk waktu dan tempat beribadah. Perubahan-perubahan yang terjadi, pada prinsipnya, tidak mengubah substansi ibadah sebagaimana yang dengan secara tegas digariskan dalam ajaran kedua agama. Hal yang berubah adalah pola atau cara beribadah yang dianggap banyak keluar dari kebiasaan yang salama ini dipraktikkan. Perubahan pola beribadah dari komunal menjadi personal, ibadah yang sebelumnya 
dilakukan di tempat-tempat ibadah kemudian dilakukan di rumah dan di tempat kerja menjadi tradisi baru bagi umat. Tradisi baru ini tidak saja dianggap sebagai dampak dari adanya pandemi Covid-19, tetapi juga dianggap sebagai media untuk semakin mendekatkan diri dengan Tuhan dan kesempatan untuk instrospeksi diri meskipun dengan tata cara yang relatif baru (Ghofur \& Subahri, 2020).

Pandemi Covid-19 dan agama memiliki ruang masing-masing sehingga keduanya sering ditempatkan pada posisi yang berbeda. Fungsi agama dalam kaitannya dengan pandemi Covid-19 pun mendua. Max Regus (2021) menegaskan bahwa agama memiliki dua sisi yang bertolak belakang dalam kaitannya dengan COVID-19. Pada satu sisi, agama memiliki aturan yang potensial untuk mengurangi atau bahkan menghentikan pandemi ini (Barmania \& Reiss, 2020; Everett, Colombatto, Chituc, Brady, \& Crockett, 2020; Fardin, 2020), tetapi di sisi lain agama juga dapat menjadi medium penyebaran Covid-19 (Ahmed \& Memish, 2020; Ebrahim, Ahmed, Gozzer, Schlagenhauf, \& Memish, 2020). Rutinitas Muslim yang setiap Jumat wajib menunaikan salat jamaah Jumat, misalnya, berubah dan lebih banyak dilakukan di rumah dan beribadah secara mandiri/munfarid (Ghofur \& Subahri, 2020; Siregar \& Jubba, 2020) dalam rangka menghindari penyebaran COVID-19. Ini sebagai respons atas adanya "kontribusi" pelaksanaan ibadah komunal terhadap klaster penyebaran virus sehingga pengalihan pola dan tempat dilakukan. Demikian halnya dengan umat Kristiani, pelaksanaan ibadah dilakukan di luar gereja. Kebaktian mingguan misalnya, dilakukan di rumah bahkan dilaksakanan secara virtual. Bahkan, perayaan Natal yang menjadi momen spesial dilaksanakan tidak seperti biasanya. Para pemuka agama Kristen melakukan prosesi peribadatan di gereja dan diikuti secara daring oleh jamaah, bahkan di rumah-rumah dilakukan ibadah yang dikenal dengan "gereja rumah" (Bryson, Andres, \& Davies, 2020; Ering, 2020). Pola beribadah seperti ini di satu sisi memang tetap menunjukkan tingginya kesalehan umat sebagai penganut agama yang taat, namun di sisi lain terdapat banyak sesuatu yang hilang karena adanya pembatasan-pembatasan dalam pelaksanaannya.

Studi-studi mengenai pandemi Covid-19 sejauh ini telah banyak dilakukan oleh para ahli. Di antara mereka, terdapat berbagai kajian yang melihat covid-19 dari aspek kesehatan, khususnya mengenai pentingnya melakukan upaya pencengahan dengan mematuhi protokol kesehatan (Mardhia et al., 2020; Ridlo, 2020; Telaumbanua, 2020; Regus, 2021). Ahli lain mengkaji Covid-19 dengan menitikberatkannya pada dampak sosial, ekonomi, bahkan politik yang ditimbulkan oleh pandemi ini (Yusup et al., 2020; Hastangka et.al, 2020). Studi yang melihat Covid-19 sebagai bagian dari urusan agama juga tidak sedikit (Abdullah, 2020; Darmawan, Miharja, Waluyajati, \& Isnaeniah, 2020; Maliki, 2020; Pabbajah et al., 2020; Qodir, Effendi, Jubba, Nurmandi, \& Hidayati, 2020). Studi-studi tersebut telah memberikan pengayaan dan pemahaman kepada publik bahwa pandemi Covid-19 bukanlah sesuatu yang berdiri sendiri sehingga dapat dikaji dari berbagai aspek. Studi ini selain meneruskan kajiankajian tersebut, juga akan melengkapinya dengan melihat bagaimana praktik beribadah umat Islam dan Kristen di tengah pandemi Covid-19.

Sejalan dengan hal di atas, artikel ini menjawab pertanyaan bagaimana bentuk strategi beragama umat Islam dan Kristen di tengah pandemi Covid-19 dan seperti apa pesan agama menyikapi kondisi tersebut. Kedua persoalan ini diurai secara rinci pada sub bab artikel ini. Artikel ini disandarkan pada asumsi bahwa umat beragama selain tetap menjalankan ibadah sesuai dengan ajaran agama, juga melakukan ibadah dengan perubahan-perubahan pola sehingga tetap melaksanakan kewajibankewajibannya meskipun di tengah pandemi Covid-19. Kondisi darurat mendukung dilakukannya berbagai ibadah dengan perubahan-perubahan yang bersifat teknis, dan tidak mengubah substansi ibadah itu sendiri. Kepatuhan atas dua perintah sekaligus yang harus ditegakkan; perintah agama dan anjuran pemerintah menjadi titik di mana umat beragama mengkompromikan sikap yang lebih proporsional tanpa meninggalkan salah satu di antara keduanya.

Artikel ini adalah hasil penelitian lapangan yang dilakukan selama pandemi Covid-19 di dua kota, yaitu Yogyakarta dan Ambon pada April-Desember 2020. Pemilihan kedua daerah ini didasarkan pada fakta bahwa praktik-praktik beribadah pada kota-kota ini sangat semarak, khususnya menjelang harihari raya, meskipun tidak memiliki perbedaan secara spesifik dengan daerah-daerah lain di Indonesia yang juga menghadapi kendala serupa. Data yang dijadikan bahan analisis diperoleh dari observasi, wawancara, dan studi kepustakaan. Observasi dilakukan terhadap pelaksanaan ibadah di masjid dan 
gereja. Selama pandemi Covid-19, pelaksanaan ibadah pada masjid dan gereja berubah total, termasuk intensitas dan pelibatan jamaah. Meskipun ibadah tetap dilakukan seperti waktu pada lazimnya, namun kehadiran umat dibatasi. Bahkan, beberapa bulan pelaksanaan ibadah Jumat tidak dilakukan secara berjamaah di masjid karena ditutup sebagai respons terhadap himbauan pemerintah (Darmawan et al., 2020). Demikian pula dengan ibadah Minggu di gereja, tidak dilakukan seperti harihari biasanya. Wawancara dilakukan terhadap tokoh agama, akademisi, dan umat kedua agama. Pertanyaan wawancara difokuskan pada cara dan tempat mereka beribadah selama pandemi Covid19 termasuk perubahan-perubahan yang dirasakan. Adapun studi kepustakaan dilakukan untuk melengkapi data yang diperoleh dari kedua metode sebelumnya. Penelusuran kepustakaan sekaligus memperkuat argumen yang dibangun dalam artikel ini. Dalam pengumpulan data, khususnya observasi dan wawancara di Kota Ambon dibantu oleh asisten peneliti mengingat kondisi yang kurang memungkinkan dilakukan secara langsung di lokasi penelitian. Data yang diperoleh dari ketiga metode ini kemudian dikelompokkan dan dianalisis dengan memberi konteks sehingga memiliki makna dan relevansi dengan argument yang dibangun.

\section{Agama dan Pancemi Covid-19 dalam Literatur}

Pandemi merupakan istilah kesehatan yang merujuk pada penyebaran penyakit yang menyerang orang dalam jumlah banyak dan terjadi di banyak tempat (Juntra et al., 2020; Ugdata et.al, 2020). Pada Desember 2019 Virus Corona (SARS-CoV-2) pertama kali diidentifikasi di wilayah Wuhan Cina (Moulahoum, Ghorbanizamani, Zihnioglu, Turhan, \& Timur, 2021) dan telah menyebabkan krisis kesehatan global (Loey, Manogaran, Taha, \& Khalifa, 2021). Wolrd Health Organization (WHO) telah menetapkan wabah yang disebabkan oleh virus corona sebagai pandemi global yang menyebar ke seluruh dunia pada tanggal 11 Maret 2020 (Baig, 2020; Cucinotta \& Vanelli, 2020; Darsono, Rohmana, \& Busro, 2020; Ghosh, Amin, Gayen, \& Jha, 2021; Lillard, 2020; Wong, Thai, Li, \& Liu, 2020). Penyakit yang disebabkan oleh Virus Corona tersebut memiliki gejala yang paling umum yaitu demam (98\%), batuk (76\%), dyspnoea (55\%) dan mialgia atau kelelahan (44\%) (Lake, 2020). Selain itu, penyakit klinis yang disebut COVID-19 ini juga disertai oleh gejala lain seperti rinorea, bersin, sakit tenggorokan, dispnea, dan hemoptysis. Virus Corona menyebabkan sindrom pernapasan akut parah (Sars-Cov-2) (Antonio Maria et al., 2020) sehingga bentuk penyakit yang parah dapat menyebabkan gagal paru dan kematian akibat cedera paru akut (Mbanuzuru, Okoro, Mbanuzuru, \& Ibeh, 2021).

Dalam kehidupan keagamaan, pandemi COVID-19 telah memengaruhi cara/praktik keagamaan dengan berbagai batasan yang telah diterapkan di seluruh dunia di mana intensitas pertemuan keagamaan harus dibatasi untuk memerangi penyebaran virus (Kowalczyk et al., 2020). Sementara itu, dalam pandangan Islam, paling tidak ada dua konsep yang harus dikaji guna memahami pandemi. Pertama, pandemi sebagai musibah yakni 'sudah pasti benar' sesuai sunnatullah yang terjadi hanya dengan seizin Allah (Maulana, 2020) dan kedua pandemi juga patut dipahami sebagai maradh atau sakit. Terlepas dari pandangan tersebut, pandemi COVID-19 telah berdampak pada kehidupan banyak orang di mana di antara strategi yang mungkin dilakukan untuk mengatasi perasaan ketidakamanan yang menyertai, agama memainkan peran penting. Di Italia misalnya, pandemi COVID-19 telah meningkatkan religiusitas masyarakat yang tampak dalam hal kehadiran di layanan keagamaan (melalui web, radio dan tv) dan doa selama pandemi (Molteni et al., 2021). Sementara itu, transmisi informasi mengambil peran penting dalam mengatasi pandemi COVID-19 yang dilakukan oleh berbagai pihak, termasuk kalangan tokoh agama di mana pesan yang disampaikan oleh tokoh agama memiliki kecenderungan untuk diikuti, sehingga tokoh agama berperan sebagai peredam kekalutan umat, corong informasi pandemi, dan figur teladan (Aula, 2020:125). Dalam Islam, ulama memiliki peran dalam mitigasi pandemi melalui dakwah dengan menggabungkan antara pengetahuan agama dengan pengetahuan saintifik (Zahratunnisa, 2020), tetapi justru pelibatan ulama sering diabaikan (Pabbajah et al., 2020).

Selama pandemi COVID-19, agama sering digambarkan sebagai masalah. Banyak orang mencari agama sebagai perlindungan dari COVID-19 tanpa melakukan pencegahan dasar seperti pembatasan sosial (Iqbal, Tareen, \& Saleem, 2020). Beberapa narasi terkadang menyiratkan (atau bahkan 
menyatakan) bahwa agama secara langsung merugikan kesehatan masyarakat atau secara tidak langsung merusak respons kesehatan masyarakat untuk COVID-19 (Barmania \& Reiss, 2020) seperti pada kasus Jamaah Tabligh di Asia Tenggara, 14.000 delegasi Jamaah Tabligh Islam di Kuala Lumpur secara luas dianggap sebagai penyebab gelombang kedua pandemi di Malaysia, di mana peserta dari acara bepergian ke Brunei, Kamboja, dan Indonesia kemudian dinyatakan positif (Che Mat, Edinur, Abdul Razab, \& Safuan, 2020). Di sini tampak bahwa jika agama diperlakukan secara sensitif dengan pengakuan dari kompleksitas masalah dan kebutuhan solusi di sejumlah level, maka ada peluang bagus bahwa beberapa dari prediksi terburuk dari konsekuensi COVID-19 mungkin tidak terjadi. Akan tetapi, jika agama diabaikan atau diremehkan COVID-19 dapat berlanjut tanpa henti di beberapa komunitas agama, maka dapat memperluas dampak pandemi global ini (Barmania \& Reiss, 2020).

Apa yang ditunjukkan oleh para ahli melalui beberapa studi ini memperlihatkan dua hal penting. Pertama, pandemi Covid-19 merupakan kondisi di mana keteraturan-keteraturan sosial yang selama ini dinikmati berubah sehingga masyarakat (umat beragama) juga menghadapi dengan mengubah perilaku hidupnya, termasuk dalam persoalan ibadah. Kedua, agama sering diposisikan sebagai alat untuk menjustifikasi aktivitas meskipun membahayakan. Sebab, meninggalkan perintah agama dipahami sebagai "pembangkangan" terhadap agama itu sendiri. Di sinilah letak dilemanya, ketika dalam waktu bersamaan terdapat dua kepentingan yang harus diakomodir. Pada satu sisi, ada perintah tegas untuk mematuhi seluruh ajaran agama dengan segala risikonya, sedangkan di sisi lain ada kondisi yang justru dapat memunculkan akibat buruk bagi pemeluk agama sendiri jika melakukannya. Namun demikian, terdapat satu hal yang penting yang dapat menjadi pertimbangan dalam beribadah, yaitu pada ajaran agama-agama juga tersimpan berbagai keringanan yang dengannya dapat memudahkan pemeluknya untuk tetap menunaikan kewajiban-kewajibannya. Misalnya, ibadah berjamaah seperti salat Jumat bagi Muslim laki-laki wajib hukumnya dan dilakukan di masjid, tetapi kewajiban tersebut gugur ketika ada kondisi yang darurat yang mengikutinya. Kondisi pandemi Covid-19 merupakan salah satu "sebab" keguguran hukum wajib ini. Dalam hal ini, peran agama yang selalu memberikan pilihan atau solusi kepada penganutnya semakin tampak sehingga apapun perintah agama selalu dilaksanakan meskipun dalam kondisi lingkungan yang kurang menguntungkan.

\section{Model Beribadah di Tengah Pandemi-Covid 19}

Bagian ini mendiskusikan tentang persoalan seperti apa perubahan pelaksanaan ibadah rutin bagi umat Muslim dan Kristiani di tengah pandemi Covid-19. Ibadah rutin memiliki beberapa fungsi yang sangat penting dalam setiap agama. Selain menjadi salah satu medium umat mendekatkan diri dengan Tuhannya, ibadah rutin juga menjadi penyambung hubungan antar-umat sehingga komunikasi dan kolektivitas tetap terjaga. Hal ini juga tidak lepas dari prinsip beragama. Dalam Islam misalnya, menjaga silaturahmi adalah salah satu akhlak terpuji, bahka di balik menjaga silaturahmi ada janji Allah. Salah Dalam satu hadis dinyatakan oleh Rasulullah: "Siapa yang suka dilapangkan rezekinya dan dipanjangkan umurnya hendaklah dia menyambung tali silaturahmi" (HR. Bukhari dan Muslim). Silaturahmi (sesama Muslim) sendiri dapat terwujud melalui pertemuan-pertemuan seperti halnya dalam pelaksanaan ibadah rutin yang bersifat berjamaah (Kurahman, 2018). Demikian pula, dalam tradisi Kristen pertemuan di tempat ibadah menjadi salah satu jalan menyambung komunikasi secara intensif meskipun pertemuan-pertemuan di berbagai tempat juga sering dilakukan (Pamungkas \& Anggana, 2019).

\section{Pelaksanaan Ibadah Rutin}

Ibadah berjamaah seperti halnya salat bagi umat Islam, memiliki beberapa makna. Pertama, dalam salat berjamaah dijanjikan akan dinaikkan derajat bagi yang mengikutinya berupa 27 derajat. Keterangan ini dapat ditemukan dalam sebuah hadis yang diriwayatkan oleh Bukhari: "Salat berjamaah melampaui salat sendirian dengan (mendapatkan) 27 derajat." Selain ganjaran atau pahala,

keistimewaan salat berjamaah juga dapat dilihat ketika seorang jamaah dalam kondisi masbuk (terlambat) dan hanya memperoleh rukuk terakhir, masih memperoleh satu rakaat jamaah meskipun 
tidak mendapatkan bacaan Al Fatihah dalam salatnya. Ia pun dihitung salat berjamaah. Kedua, dalam pelaksanaan salat secara berjamaah tercermin adanya komunalitas umat yang terus terbentuk secara sistemik. Kebersamaan yang terbentuk selain dipengaruhi oleh adanya pemahaman bersama atas dasar keutamaan dan posisi sadar sebagai hamba, seperti yang telah disebutkan sebelumnya, juga didukung oleh adanya rasa persaudaraan yang erat di antara muslim. Ada pesan utama di sini, yaitu semangat kesederajatan di kalangan umat Islam. Ketiga, dalam salat jamaah termaktub pesan atas pentingnya membangun barisan secara bersama atas satu komando. Kebersamaan yang kuat lahir dari ikatanikatan personal yang memiliki komitmen yang sama. Dalam hal ini, ada kode etik yang harus dipatuhi dalam berjamaah, yaitu komando ada di tangan imam sehingga jamaah mengikutinya. Sebab, jika tidak mengikuti secara otomatis derajat berjamaah pun gugur. Inilah berkah dari ibadah berjamaah, dimana di dalamnya tersimpan keberkahan dan kebersamaan sekaligus.

Di masa pandemi Covid-19, idealitas beribadah secara berjamaah berubah drastis. Pelaksanaan ibadah rutin tidak lagi dilakukan di masjid atau gereja, tetapi dilaksanakan di rumah-rumah. Orang yang terlibat pun sangat terbatas, dalam hal ini hanya melibatkan anggota keluarga yang ada di rumah. Seruan adzan sebagai penanda masuknya waktu salat tetap dikumandangkan dari masjid-masjid, namun jamaah tetap menunaikan salat di rumah masing-masing. Tidak sedikit umat Muslim menjalankan salat Jumat secara terbatas baik di rumah maupun di tempat kerjanya. Seorang agamawan dan akademisi, FA, mengungkapkan bahwa ia selama kurang lebih lima bulan tidak menunaikan salat Jumat di masjid. Padahal, salat Jumat bagi Muslim laki-laki hukumnya wajib (wajib 'aini), yaitu kewajiban yang melekat pada diri setiap orang. Ia mengatakan:

Untuk salat jamaah tetap dilakukan di rumah dan jamaahnya anak dan istri. Saya juga tidak pernah berjamaah di masjid pada masa itu. Pokoknya salat dilakukan di rumah dan menjauhi kerumunan banyak orang seperti berjamaah di masjid" (FA, Komunikasi Personal, 20 Oktober 2020).

QZ, yang memiliki kesibukan sebagai tenaga pengajar juga mengakui tidak menunaikan kewajibannya (salat Jumat berjamaah) dalam beberapa bulan. Salat Jumat digantinya dengan salat Dhuhur. Hal ini memang memiliki dasar hukum yang jelas dalam Islam, di mana salat Jumat yang harusnya dilakukan secara berjamaah dapat diganti dengan salat Dhuhur dan dapat dilakukan secara mandiri atau berjamah. QZ mengatakan:

Pada awal pandemi, kami tidak melaksanakan jumatan. Salat dilakukan di rumah dan diganti dengan empat rakaat salat Dhuhur. Ini darurat jadi kami memilih opsi itu sekaligus mematuhi himbauan pemerintah. Kami beberapa bulan salat di rumah, tidak ke masjid meskipun ada janji pahala yang berlipat ganda jika melakukan salat jamaah dan dilakukan di masjid" (QZ, Komunikasi Personal, 22 Oktober 2020).

Bagi mereka, menunaikan ibadah adalah kewajiban yang tidak boleh ditinggalkan. Oleh karena itu, pelaksanaannya pun mengikuti kondisi. Sebab, dalam ajaran Islam memang terdapat beberapa kondisi di mana keringanan-keringanan dapat dipilih dan hal itu sah. Dalam Islam, jika ada kondisi darurat atau ada uzur maka terdapat pula keringanan di dalamnya. Hal ini didasarkan pada keterangan ayat dan hadis yang menunjukkan bahwa dalam kondisi "terpaksa", sesuatu yang dilarang pun diperbolehkan "dilanggar" namun dalam batasan tertentu. Dalam persoalan makan misalnya, memakan makanan yang diharamkan seperti daging Babi dan lain-lain diperbolehkan jika dalam keadaan "sangat lapar" dan jika sekiranya tidak dimakan akan membahayakan jiwa misalnya dapat meninggal dunia akibat kelaparan. Hal ini dapat dilihat pada Q.S An Nahl ayat 115:

Sesungguhnya Allah Hanya mengharamkan atasmu (memakan) bangkai, darah, daging babi dan apa yang disembelih dengan menyebut nama selain Allah; tetapi barangsiapa yang terpaksa memakannya dengan tidak menganiaya dan tidak pula melampaui batas, Maka Sesungguhnya Allah Maha Pengampun lagi Maha Penyayang.

Ayat tersebut memberikan penjelasan bahwa dalam kondisi "terpaksa", hukum memakan sesuatu yang diharamkan berubah dalam batasan tertentu. Bangkai, darah, dan daging babi misalnya, yang pada asalnya haram dimakan, diperbolehkan oleh syariat agama jika dalam kondisi terpaksa. Dalam 
hal ini, kondisi terpaksa adalah kondisi darurat yang harus disikapi dengan baik sehingga menghindarkan diri dari ancaman kelaparan bahkan kematian. Dalam beberapa ayat lain juga ditemukan hal yang sama dimana keharaman benda (sesuatu) atau makanan gugur atau berubah hukum ketika dalam kondisi darurat, dalam hal ini seseorang terpaksa memakannya dengan alasan yang sangat mendesak. Dalam konteks menghadapi pandemi Covid-19, fatwa Majelis Ulama Indonesia (MUI) Nomor 14 Tahun 2020, menempatkan kondisi pandemi dalam kategori darurat sehingga kewajiban beribadah seperti berjamaah menjadi gugur.

Dalam tradisi agama Kristen juga demikian, ibadah komunal yang lazimnya dilakukan di gerejagereja juga mengalami perubahan dari aspek model pelaksanaan, meskipun tidak mengubah substansinya. Ibadah hari Minggu yang biasanya dilakukan secara bersama-sama di gereja bergeser tempatnya dilakukan di rumah-rumah dengan jumlah jamaah terbatas. Ibadah hanya melibatkan keluarga inti dan beberapa anggota keluarga lainnya. Umat kristiani selama pandemi Covid-19 lebih banyak melakukan ibadah di rumah. YZR, seorang akademisi memilih beribadah di rumah dengan alasan berusaha menghindari kemungkinan penyebaran virus jika bersentuhan dengan banyak orang. Ia juga mengatakan, kebijakan pemerintah tentang pembatasan pelaksanaan ibadah secara komunal atau berjamaah di gereja-gereja tidak mengubah substansi ajaran dan pelaksanaan ibadah. "Kami melaksanakan ibadah di rumah, bahkan perayaan Natal kami tidak ke mana-mana. Di rumah lebih aman" (YZR, Komunikasi Personal, 28 Desember 2020).

Umat kristiani melaksanakan ibadah di rumah meskipun sebelumnya lebih banyak dilakukan di gereja dengan banyak jamaah. Beribadah di luar gereja bukanlah model yang diimpikan, tetapi bentuk beribadah yang melibatkan banyak orang (Hutahaean, 2020). Sebab, persekutuan Kristiani lahir komunalisme dalam satu kegiatan melalui tata ibadah sehingga antara satu dengan yang lain merasakan kedekatan yang luar biasa di dalam Kristus (Siringoringo, 2016). Umat kristiani menyadari bahwa di masa pandemi Covid-19 ini, suasana pelaksanaan ibadah berubah drastis.

Sebagai respons terhadap kebijakan pemerintah, ibadah rutin Mingguan lebih banyak dilakukan di luar gereja dengan melibatkan jamaah yang sangat terbatas dan dengan tata aturan gereja (Hutahaean, 2020). Umat Kristiani mengakui bahwa ada suasana yang hilang di masa pandemi Covid19 ini. Kebiasaan saling bertegur sapa setelah melaksanakan ibadah tidak lagi seperti sebelumnya. Mereka hanya saling berpandangan, senyumnya pun tidak terlihat akibat penggunaan masker. Kebiasaan lain seperti pulang bersama berubah dengan hanya pulang dengan keluarga masingmasing. Ini pun masih dipenuhi dengan perasaan yang "aneh" karena jamaah yang lain juga melakukan hal serupa sehingga kehadirannya di gereja hanya seperti "numpang lewat". Di antara mereka ada yang memperhatikan dan mengutarakan perasaannya bahwa gereja sangat sepi karena tidak didatangi oleh jamaah setiap Minggu seperti waktu-waktu sebelumnya.

Pelaksanaan ibadah rutin bagi kedua kelompok agama mengalami perubahan-perubahan mendasar pada aspek teknis pelaksanaan, namun tetap pada substansi ibadah yang sesuai dengan ajaran agama. Ibadah yang selama ini umumnya dilakukan di tempat-tempat ibadah (masjid dan gereja) pada masa pandemi dilakukan di rumah masing-masing. Suasana semarak karena diikuti oleh banyak orang (jamaah) menyimpan pesan yang sangat dalam, bahwa agama memang bukan kepemilikan yang bersifat personal tetapi komunal sehingga jika ibadah dilalukan secara terbatas terasa ada keanehan di dalamnya, yaitu kehilangan semangat kebersamaan. Suasana semarak bergeser menjadi pemandangan ibadah yang sepi. Namun demikian, suasana ini tidak berujung pada hilangnya semangat beragama di kalangan umat karena mereka tetap melakukan ibadah dengan tuntunan agama yang secara prinsip tetap sama.

\section{Merayakan Hari Raya dengan Pembatasan}

Selain ibadah ritual yang dilakukan setiap hari dan mingguan, umat juga dihadapkan pada tuntutan perubahan pola ibadah yang sifatnya komunal tahunan. Pelaksanan ibadah tahunan seperti Idul Fitri/Idul Adha dan Natal dilakukan sama dengan pola ibadah lain yang tidak melibatkan banyak orang atau jamaah. Perayaan Idul Fitri/Idul Adha bagi umat Muslim dilakukan secara semarak. Momen ini bahkan merupakan ibadah tahunan yang ditunggu kedatangannya oleh umat Muslim. 
Momen perayaan lebaran ini tidak saja menjadi momen penting beribadah, tetapi juga waktu untuk bertemu sanak famili yang jarang bertemu sebelumnya. Perayaan lebaran menjadi peristiwa tahunan sekaligus menjadi media komunikasi di antara umat (Yanti, 2019) karena di dalamnya menyimpan sejumlah "berkah" yang hanya datang sekali setahun. Bagi masyarakat perantau, lebaran menjadi masa yang sangat baik untuk "mudik" atau pulang ke tanah kelahirannya. Sangat jarang, peristiwa ini terlewatkan mengingat perayaan lebaran juga diikuti oleh waktu libur sekolah dan libur kerja (cuti) yang dapat dimanfaatkan secara maksimal. Seorang tenaga pendidikan pada Perguruan Tinggi Negeri di Yogyakarta bahkan menyiapkan diri dua tahun dengan menabung untuk persiapan lebaran di tanah kelahirannya. Ia menyatakan:

Sejak dua tahun lalu kami mengirit pengeluaran untuk persiapan kembali ke kampung. Saya sebagai pengajar dengan tekun menyelesaikan berbagai tugas dan melakukan aktivitas yang mendukung saving uang untuk akomodasi di kampung. Lebaran sangat dirindukan khususnya kami sekeluarga. Ini juga digunakan untuk anak-anak mengenal keluarga besarnya. Tahun ini kami lebaran bersama di rumah dengan jamaah anak-anak dan istri saja (AS, Komunikasi Personal, 12 November 2020).

Sejalan dengan pernyataan ini, PM, seorang pengajar pada salah satu Peruguran Tinggi Swasta dan tokoh agama di Yogyakarta juga mengakui bahwa perayaan lebaran di kampung halaman menajdi peristiwa yang sangat dinantikan. Baginya, perayaan lebaran adalah waktu bertemu dengan keluarga untuk melepas kerinduan karena telah lama tidak bertemu secara fisik. Ia menyatakan:

Saya menjadwalkan pulang setiap tahun untuk lebaran. Akan tetapi, akibat Covid-19 ini tidak pulang. Lebaran saja dilakukan di rumah. Jadi perasaan semarak tidak dirasakan lagi. Dulu perayaan lebaran kalua tidak di lapangan ya di masjid. Tahun ini kami lebaran di rumah (PM, Komunikasi Personal, 15 November 2020).

Pernyataan PM ini menegaskan bahwa tradisi pulang kampung (mudik) dan merayakan lebaran bersama telah menjadi bagian dari kehidupan masyarakat Muslim. Momen ini bahkan menjadi waktu yang dinantikan karena memiliki makna dan fungsi ganda. Mereka juga mengakui bahwa pandemi Covid-19 mengubah banyak hal. Bagi banyak orang (Muslim), mudik dan merayakan lebaran di kampung "batal" karena kondisi yang memang tidak memungkinkan. Kondisi ini bahkan menjadi jalan untuk mempersiapkan diri secara matang untuk tahun depan.

Dampak pandemi Covid-19 juga sangat dirasakan oleh umat Kristiani. Tradisi "Natalan" yang di dalamnya diisi dengan aktivitas yang penuh suka cita berubah ketika pandemi Covid-19 berlangsung. Umat Kristiani tidak lagi merayakan Natal dengan penuh suka cita di gereja-gereja yang diikuti dengan suasana riang gembira dan menjadi medium pertemuan antar-jamaah, tetapi telah berubah menjadi ibadah kolektif terbatas karena pelaksanaannya tidak melibatkan banyak orang dan dilakukan di rumah-rumah. Perayaan Natal dilakukan secara mandiri dengan melibatkan lingkup keluarga saja. Sebagai bentuk komitmen gereja memberikan pelayanan kepada jamaahnya, dilakukan ibadah komunal dengan menggunakan fasilitas teknologi. Gereja seperti lazimnya melaksanakan ibadah pada waktu yang sama, namun dilakukan secara daring atau virtual. Semua jamaah dapat mengikuti ibadah dari rumah masing-masing dengan menyaksikannya melalui media yang ada. Pesan Natal pun disampaikan oleh Pendeta di mimbar, segala prosesi ibadah pun dilakukan dengan penuh hikmat seperti ibadah di luar suasana pandemi Covid-19.

Perayaan Natal 2020 adalah perayaan yang sangat berbeda. Natal adalah momen di mana umat Kristiani saling bertemu, saling menyapa, saling memperlihatkan kebahagiaan, makan bersama, dan sebagaimnya. YN, seorang umat Kristiani mengatakan:

Natal tahun ini (2020, pen.), tidak ada saling berkunjung dan dikunjungi antar tetangga, kolega, dan saudara. Padahal momen natal adalah salah satu momen dimana kita bisa saling berjumpa, makan bersama, berbagi cerita satu dengan yg lain (YN, Komunikasi Personal, 26 Desember 2020).

YN menambahkan bahwa perayaan Natal di gereja hanya ia ikuti bersama suaminya, anak-anak tidak ikut karena aturan pembatasan oleh pihak penyelenggara ibadah (gereja). 
Ibadah natal di gereja hanya diikuti oleh saya dan suami karena anak-anak dan lansia dilarang ibadah di gereja. Padahal mengikuti ibadah bersama di gereja dengan orang tua dan anak-anak serasa memiliki rasa tersendiri. Ada rasa bahagia jika bisa menjalani ritual khusus itu secara bersama. Orang tua dan anak-anak kami mengikutinya secara virtual di rumah saja (YN, Komunikasi Personal, 28 Desember 2020).

Ia juga menyadari bahwa dampak pandemi Covid-19 mengubah banyak hal dalam tradisi peranyaan Natal dalam komunitasnya.

Saya dan keluarga saya hanya di rumah saja dan hanya memberi salam ala corona saat pergi atau pulang ibadah natal saja. Selebihnya hanya lewat media sosial. Kalau saya merasa seperti tidak ada perayaan natal. Padahal kalau berada di luar Ambon, suasana natal adalah suasana yang paling dirindukan karena perjumpaan, makan Bersama dan berbagi cerita bersama seorang dengan yang lain, yang tidak dirasakan kalau di luar daerah. Natal adalah salah satu momen dimana kami kumpul keluarga, teman dan juga sahabat. Tapi Covid-19 membatasi semuanya (YN, Komunikasi Personal, 27 Desember 2020).

Adanya perubahan dan merayakan Natal yang berbeda juga diungkapakan oleh RK, seorang tokoh Kristen. Pandemi Covid-19 telah mengubah banyak tradisi beribadah khususnya Natal tahun 2020. Perubahan menyikapi kondisi ini didukung oleh adanya protokol kesehatan yang ketat di gereja sehingga jumlah jamaah sebelumnya tidak dibatasi, Natal tahun ini sangat dibatasi. Ada beberapa kebiasaan yang tidak dilakukan seperti jabat tangan (bersalaman). Demikian pula, kunjungan antarkeluarga ke kerumah dan keluarga yang lain tidak dilakukan. Ia mengakui:

Perayaan natal tetap dilakukan di gereja bersama jemaat dengan gunakan prokes, dengan tidak berjabat tangan, menyapa namun dengan masker sehingga tidak bisa melihat senyum sapa saudara seiman yang lain. Kebiasaan saat malam natal saat pergantian waktu jadi berbeda karena tidak dapat berkunjung ke tetangga sebelah rumah untuk bersalaman mengucapkan Natal. Kebiasaan pada saat Natal, anak-anak dari lingkungan atau dari tempat lain berkunjung ke rumah untuk berslaman dan dijamu oleh tuan rumah tidak terjadi seperti tahun kemarin (RK, Komunikasi Personal, 28 Desember 2020).

Bagi RK, suasana Natal tahun 2020 sangat berbeda dengan tahun-tahun sebelumnya. Namun, ia juga menegaskan bahwa "Suasana kebersamaan pada saat moment Natal menjadi berbeda walaupun tidak mengurangi makna Natal. Namun sangat mempengaruhi situasi Natal pada tahun ini (2020, pen.)" (RK, Komunikasi Personal, 28 Desember 2020).

Perubahan dalam perayaan Natal 2020 juga dirasakan oleh YZR, seorang akademisi/Kristiani. Baginya, Natal di rumah meskipun secara substansi tidak berubah tetapi ada pelaksanaannya yang "sepi" sangat dirasakan. Ia menyatakan:

Pengalaman di Kota Ambon dan Maluku secara keseluruhan menunjukkan bahwa perayaan

Natal pada masa pendemi Covid-19 turut mengubah tradisi perayaan Natal dikalangan masyarakat setempat (YZR, Komunikasi Personal, 28 Desember 2020).

Hal serupa juga disampaikan oleh RW, seorang Pendeta, yang sehari-hari melayani jemaat. Pada masa pandemi Covid-19, banyak hal yang berubah di kalangan jemaat. Ia mengatakan:

Yang berubah dari perayaan Natal sebelum adalah selain gereja/jemaat tidak melakukan banyak perayaan natal, juga kunjungan dalam perayaan natal dibatasi, masing-masing tetap dirumah saja (RW, Komunikasi Personal, 26 Desember 2020).

Suasana sepi perayaan Natal juga diungkapkan oleh jemaat. NA, salah seorang jemaat gereja mengatakan bahwa tahun ini ada perubahan suasana.

Suasana Natal tahun ini kurang meriah seperti tahun-tahun sebelem. Anak-anak juga hanya sedikit saja yang jalan dari rumah-kerumah dikomplok kami. Saya, suami dan anak merayakan Natal di rumah, bersama keluarga besar yang ada (NA, Komunikasi Personal, 27 Desember 2020).

Suasana peranyaan Natal yang berbeda menjadi momen lain yang dirasakan oleh umat Kristiani tahun 2020. Perayaan yang "diatur" oleh protokol kesehatan meskipun secara substansi tidak 
mengubah makna perayaan Natal, namun mengubah kebiasaan-kebiasaan yang sebelumnya sangat lekat dengan suasana kegembiraan berkurang. Perayaan Natal yang berdekatan dengan pergantian Tahun Baru menyimpan kesan bagi umat Kristiani dan masyarakat umum. Ada suasana keceriaan yang hilang pada perayaan Natal kali ini, ini disampaikan oleh beberapa jemaat gereja. Perubahan kondisi lingkungan, paling tidak telah menjadi media bagi penting dari perjalanan hidup bangsa dan masyarakat dunia tahun 2020 ini. Kehadiran teknologi, sedikit banyak, telah memfasilitasi umat beragama untuk menunaikan ibadah dengan baik dan tetap dalam kerangka ajaran agamanya masingmasing. Ibadah virtual seperti live streaming, YouTube, Instagram (Hutahaean, 2020) meskipun tidak diikuti secara langsung di gereja-gereja, namun tetap memiliki makna yang dalam atas kesadaran umat untuk terus menunjukkan posisi dirinya sebagai jamaat yang taat menjalankan ajaran-ajaran agamanya.

Praktik beribadah yang tidak sepenuhnya manual dengan datang langsung ke tempat-tempat ibadah menegaskan kembali bahwa antara agama dan teknologi pada kondisi tertentu sangat sejalan. Bahkan, ibadah yang lazimnya dilakukan secara berjamaah dan berkumpul bersama, dapat melibatkan jamaah yang lebih banyak lagi dengan fasilitas ibadah online. Namun demikian, tidak semua ibadah dapat dilakukan dengan system online seperti halnya salat bagi umat Islam. Akan tetapi, paling tidak penggunaan teknologi dalam beribadah tidak saja sebagai satu upaya membantu mencegah penyebaran virus, tetapi juga teknologi telah dijadikan sarana pendukung pelaksanaan ibadah yang memudahkan umat beragama untuk melakukan rutinitasnya di tengah pandemi Covid-19. Namun demikian, pada tataran praktik ada kesulitan bagi umat beragama meninggalkan tradisi beribadah yang sebelumnya dilakukan secara kolektif (Darmawan et al., 2020).

\section{Pesan Agama di Era Pandemi Covid-19}

Tahun 2020 merupakan tahun pandemi yang di dalamnya peristiwa-peristiwa keagamaan dilakukan tidak seperti biasanya. Uraian di atas memberikan gambaran dan penjelasan atas adanya perubahan-perubahan secara mendasar, tidak saja pada waktu pelaksanaan ibadah, tetapi juga pada pola beribadah yang disesuaikan dengan kondisi darurat akibat kondisi lingkungan yang kurang kondusif. Kondisi yang mengundang kekhawatiran hampir semua orang, disikapi oleh pemerintah dengan mengeluarkan sejumlah kebijakan seperti pembatasan social (social distancing) yang bertujuan untuk mengurangi kerumunan orang dalam satu tempat. Demikian pula kebijakan Pembatasan Sosial Berskala Besar (PSBB) yang pernah diterapkan pada daerah-daerah tertentu seperti di DKI Jakarta dan Jawa Barat, serta daerah lainnya (Zahrotunnimah, 2020). Kebijakan Pemberlakuan Pembatasan Kegiatan Masyarakat (PPKM) juga sama, sebuah upaya untuk menekan penyebaran virus dan menunjukkan upaya bahwa pandemi Covid-19 harus direspons juga secara social (Chitsamatanga \& Malinga, 2020). Kebijakan seperti ini juga dilakukan oleh negara-negara lain, bahkan telah sukses menekan angka penyebaran COVID-19 seperti yang dilakukan oleh pemerintah Vietnam (Phuong, 2021).

Misi penting di balik berbagai kebijakan dan upaya pemerintah tersebut selalu saja menimbulkan masalah lain, tidak terkecuali "tuduhan" pembatasan beribadah bagi umat beragama. Larangan mendatangi tempat ibadah dan beribadah secara komunal (berjamaah) memicu kontroversi di tengah masyarakat mengingat adanya anjuran agama untuk melakukan ibadah secara berjamaah, seperti halnya salat wajib berjamaah bagi umat Muslim dan lebih utama dilaksanakan di masjid (Rajab, 2020). Meskipun dalam salah satu kaidah dinyatakan bahwa "Asal dalam perintah menunjukan arti wajib" kecuali ada dalil yang memalingkannya". Hukum dasar perintah adalah sebuah kewajiban yang harus dilaksanakan, sebab jika diabaikan terdapat dosa padanya. Dalam hal ini, jika terdapat ancaman atas keselamatan jiwa atasnya, maka kewajiban itupun dapat doleh ditinggalkan. Hanya saja, umat tidak jarang menunjukkan perasaan keagamaannya secara berlebihan sehingga "mengabaikan" keselamatan jiwanya. Bahkan dalam sebuah hadis ditegaskan mengenai kehati-hatian menjaga diri, termasuk tidak keluar-masuk ke dan dari daerah yang sedang terjadi wabah.

Jika kamu mendengar wabah di suatu wilayah, maka janganlah kalian memasukinya. Akan tetapi, jika terjadi wabah di tempat kamu berada, maka jangan tinggalkan tempat itu" (H.R al-Bukhari). 
Dalam konteks Indonesia, kebijakan pembatasan jarak dan PSBB yang dikeluarkan pemerintah menjadi sangat relevan. Sebab, tujuan kebijakan tersebut sangat jelas yaitu menjaga segala kemungkinan penyebaran virus yang secara langsung juga berdampak pada keselamatan orang banyak.

Kebijakan social distancing sebagai salah satu upaya mengurangi penyebaran virus, termasuk yang berskala besar (Adrian, 2020; Hadi, 2020); tidaklah dimaksudkan untuk memutus relasi-relasi sosial masyarakat. Pembatasan jarak hanya bersifat fisik yaitu menjaga jarak aman agar dapat mencegah penularan virus atau penyakit. Akan tetapi, jarak secara ruhani tidak bisa dijauhkan dari setiap orang. Tanggungjawab sosial, saling peduli, tolong menolong, toleransi, dan lain-lain tidak boleh renggang. Sebab, dalam perintah agama tersimpan pesan bagaimana beribadah dengan tidak membahayakan jiwa. Social distancing justru menjadi momen untuk terus mendekatkan diri secara "perasaan" dengan sesama manusia. Konsep "saudara seiman" dalam agama memang tidak secara persis sama dengan "saudara sedarah" yang memiliki genealogi yang dapat disusun dengan baik. Persaudaan yang dilandasi iman mensyaratkan adanya kesamaan "rasa" dalam menjalankan ajaran agama.

Pesan penting agama di era pandemi Covid-19 ini adalah kepatuhan. Kepatuhan tidak hanya terhadap perintah agama, tetapi juga kepatuhan terhadap kebijakan negara yang memiliki semangat yang sama, yaitu menjaga keselamatan manusia/rakyat sebagai salah satu implementasi dari maqashid syariah. Hal ini juga tidak bisa dilepaskan dari penegasan Al-Qur'an mengenai perintah untuk taat kepada Allah, Rasul, dan bahkan pemerintah/pemimpin. Dalam Al-Qur'an ditegaskan:

Wahai orang-orang yang beriman, taatilah Allah dan taatilah Rasul (Nya), dan kepada para pemimpin di antara kamu. Kemudian jika kamu berselisih pendapat tentang sesuatu, maka kembalikanlah ia kepada Allah dan RasulNya, jika kamu benar-benar beriman kepada Allah dan hari akhir. Yang demikian itu lebih utama dan lebih baik akibatnya" (QS. An-Nisa [4]: 59).

Pada QS. An-Nisa [4]: 59, terdapat tiga tujuan ketaatan; Allah, Rasul, dan pemimpin. Taat kepada Allah dan Rasul-Nya adalah perintah yang juga termaktub dalam rukun Iman, artinya jika seorang Muslim mengingkarinya maka ia pun dianggap tidak beriman. Persoalan yang masih diperdebatkan di sini adalah ketaatan kepada pemimpin. Sebab, sering muncul pertanyaan, pemimpin yang mana? Akan tetapi, dalam konteks pandemi Covid-19 ini, tidak ada perbedaan mendasar mengenai perintah agama untuk menjaga diri dengan kebijakan pemerintah mengenai pembatasan sosial, misalnya, dalam kerangka menyelamatkan jiwa manusia.

Kebijakan 3 M (memakai masker, mencuci tangan, dan menjaga jarak) memang jika dicari dalilnya tidak ada, tetapi substansi dari kebijakan ini adalah demi menyelamatkan jiwa maka ia pun sebaiknya dipatuhi atau ditaati karena di baliknya sangat jelas misi ajaran agama yang ingin ditegakkan. Akan tetapi, terdapat beberapa kaidah fikih yang menjadi landasan bagaimana mengantisipasi bahaya meskipun di dalamnya juga ada manfaat. Kaidah fikih seperti "dar'u al-mafasid muqaddamun 'ala jalbi almashalih" (mencegah kerusakan/keburukan lebih diutamakan daripada mencarai sebuah manfaat). Kaidah ini sangat relevan dengan tagline "lebih baik mencegah daripada mengobati". Demikian pula, kaidah fikih "la dlarara wa dlirara" (tidak boleh membahayakan diri dan orang lain), artinya tidak boleh melakukan sesuatu perbuatan yang membahayakan diri sendiri ataupun orang lain, meskipun ada hak di dalamnya tetapi tetap memperhatikan kepentingan orang lain. Kaidah-kaidah ini menempatkan keselamatan jiwa sebagai basis perbuatan. Perbuatan "wajib" jika ada ancaman jika dilaksanakan, hukum wajibnya gugur jika ada keburukan yang mengancam jika ditunaikan. Social distancing, dalam hal ini, erat kaitannya dengan pelaksanaan ibadah berjamaah (komunal) seperti salat Jumat/jamaah, sehingga hukum wajibnya pun gugur atas dasar "menjaga keselamatan diri dan orang lain". Pada konteks ini pula, dibutuhkan kerjasama (tolong-menolong) dan saling pengertian (toleran), serta patuh di antara pemerintah dan rakyat untuk mewujudkan keselamatan bersama.

Uraian di atas memperlihatkan bahwa saling memahami atau toleran terhadap pihak lain merupakan wujud dari ketaatan beragama. Mematuhi kebijakan pemerintah yang tertuang dalam Protokol Kesehatan, menjadi bagian yang tidak terpisahkan dari ketaatan beragama itu sendiri. Bentuk saling memahami yang lain adalah toleran terhadap keberadaan umat lain selain kelompok sendiri. Pada tahun 2020, di mana banyak pihak menyebutkan sebagai tahun pandemi Covid-19 menyimpan 
sejumlah pesan yang juga tidak bisa dilepaskan dari pesan agama-agama. Kebijakan pembatasan untuk beraktivitas di luar rumah, bahkan beribadah bukanlah regulasi tanpa dasar. Sebab, dalam perintah agama mana pun selalu ada ruang dan alternatif yang meringankan pemeluk-pemeluknya untuk melaksanakan perintah dalam kondisi mendesak sehingga tampak bahwa agama membawa kemudahan-kemudahan bagi manusia. Selain itu, kondisi pandemi Covid-19 mensyaratkan umat beragama lebih sabar dan patuh dalam menghadapi kondisi, termasuk perubahan perubahanperubahan pola beribadah yang dianggap keluar dari kelaziman, bahkan ajaran agama.

\section{Kesimpulan}

Kondisi pandemi Covid-19 membutuhkan sikap yang terbuka dan "fleksibel" bagi umat beragama untuk memadukan dua kepentingan yang berbeda. Ketika ajaran agama memerintahkan untuk beribadah secara komunal diperhadapkan pada ragam aturan pemerintah, maka banyak hal yang sebaiknya dikompromikan. Sebab, pola beribadah di masa pandemi Covid-19 tidak saja menunjukkan hadirnya strategi baru umat untuk tetap menaati perintah agamanya, tetapi juga menegaskan kembali bahwa agama memberikan ruang keleluasaan bagi pemeluknya untuk melakukan ijtihad dan ikhtiar sehingga aktivitas yang bertujuan untuk semakin mendekatkan diri dengan Tuhan tetap berjalan meskipun dalam kondisi darurat. Kedaruratan dalam konteks ajaran agama memberikan peluang adanya "pelanggaran" hukum yang sifatnya temporan dan kasuistik seperti halnya terjadinya perubahan pola beribadah akibat pandemi Covid-19.

Perubahan pola beribadah terjadi sebagai respons umat beragama terhadap kondisi pandemi Covid-19 yang mengubah banyak kebiasaan. Kebijakan pemerintah mengenai pembatasan social dan lain-lain menjadi ikhtiar bersama dalam rangka menjaga keselamatan jiwa orang banyak. Keselamatan jiwa dalam ajaran mana pun menjadi hal yang sangat pokok. Penghargaan terhadap keselamatan jiwa pada kondisi tertentu dapat mengubah arah hukum, seperti halnya kewajiban beribadah berjamaah gugur karena kondisi yang kurang mendukung. Perubahan pola beribadah pada dasarnya hanya pada permukaan ajaran, tanpa mengubah substansi ajaran agama. Akan tetapi, kondisi umat memang terdapat kendala ketika membandingkan dengan suasana beribadah sebelum pandemi Covid-19. Pada masa "darurat", perubahan pola beribadah mengakomodasi tiga kepentingan sekaligus; ajaran agama, semangat umat dalam beragama, dan tanggungjawab pemerintah.

Ajaran agama yang menitik-beratkan pada bagaimana kepatuhan-kepatuhan umat terbentuk melalui ibadah-ibadah (personal dan komunal), dihadapkan pada kebijakan pemerintah yang "dianggap" bertolak belakang dengan ajaran agama itu sendiri. Kebijakan pemerintah yang membatasi ruang gerak pelaksanaan ibadah (komunal) sebaiknya disikapi dengan kesadaran bersama bahwa di balik kebijakan tersebut semata-mata bertujuan untuk melindungi dan menjamin keselamatan jiwa umat beragama. Oleh karena itu, kepatuhan baik terhadap ajaran agama maupun atas kebijakan pemerintah menjadi ruang bagi umat beragama untuk menyiasati kondisi pandemi Covid-19 ini dengan tetap dalam kerangka umat beragama yang taat. Kepatuhan terhadap ajaran agama tidak bisa berdiri sendiri di tengah kondisi pandemi Covid-19, karena umat beragama juga merupakan "umat negara" yang harus mematuhi aturan-aturan pemerintah yang memiliki misi tertentu. Artikel ini hanya membahas kondisi yang melingkupi dua kelompok agama sehingga masih dibutuhkan kajian serupa dengan melihat kondisi yang dialami oleh kelompok-kelompok agama lain dalam menyiasati kondisi darurat seperti pandemi Covid-19. 


\section{Referensi}

Abdullah, M. A. (2020). Mendialogkan Nalar Agama dan Sains Modern di Tengah Pandemi Covid-19. MAARIF, 15(1), 11-39. https://doi.org/10.47651/mrf.v15i1.75

Adrian, K. (2020). Pentingnya Menerapkan Social Distancing Demi Mencegah COVID-19. Diambil dari Alodokter.Com website: https://www.alodokter.com/pentingnya-menerapkan-social-distancing-demimencegah-covid-19

Ahmed, Q. A., \& Memish, Z. A. (2020). The cancellation of mass gatherings (MGs)? Decision making in the time of COVID-19. Travel medicine and infectious disease, 34, 101631.

Ansori, M. H. (2020). Wabah COVID-19 dan kelas sosial di Indonesia. THC Insight, (14).

Antonio Maria, G., Vasileios, P., Giacomo Piero, I., Ai Ling Loredana, R., Marco, R., Giulia, G., ... Gregori, A. (2020). Urologic surgery and invasive procedures during coronavirus pandemic: Retrospective comparison of risk infection in a referral Covid hospital and in a free-Covid hospital. Urologia Journal, 87(4), 163-166. https://doi.org/10.1177/0391560320927106

Baig, A. M. (2020). Updates on What ACS Reported: Emerging Evidences of COVID-19 with Nervous System Involvement. ACS Chemical Neuroscience, 11(9), 1204-1205. https://doi.org/10.1021/acschemneuro.0c00181

Barmania, S., \& Reiss, M. J. (2020). Health promotion perspectives on the COVID-19 pandemic: The importance of religion. Global Health Promotion, 175797592097299. https://doi.org/10.1177/1757975920972992

Bryson, J. R., Andres, L., \& Davies, A. (2020). COVID-19, virtual church services and a new temporary geography of home. Tijdschrift voor economische en sociale geografie, 111(3), 360-372.

Che Mat, N. F., Edinur, H. A., Abdul Razab, M. K. A., \& Safuan, S. (2020). A single mass gathering resulted in massive transmission of COVID-19 infections in Malaysia with further international spread. Journal of Travel Medicine, 27(3). https://doi.org/10.1093/jtm/taaa059

Cucinotta, D., \& Vanelli, M. (2020). WHO declares COVID-19 a pandemic. Acta Biomedica, 91(1), $157-160$. https://doi.org/10.23750/abm.v91i1.9397

Darmawan, D., Miharja, D., Waluyajati, R. S. R., \& Isnaeniah, E. (2020). Sikap Keberagamaan Masyarakat Menghadapi Wabah COVID-19. Religious: Jurnal Studi Agama-Agama dan Lintas Budaya, 4(2), 115-124. https://doi.org/10.15575/rjsalb.v4i2.8596

Darsono, D., Rohmana, J. A., \& Busro, B. (2020). Against COVID-19 Pandemic: Bibliometric Assessment of World Scholars' International Publications related to COVID-19. Jurnal Komunikasi Ikatan Sarjana Komunikasi Indonesia, 5(1). https://doi.org/10.25008/jkiski.v5i1.356

Dipna Videlia Putsanra. (2020). Arti PSBB yang Dibuat untuk Cegah Penyebaran Corona di Indonesia. Diambil dari Tirto.id website: https://irto.id/arti-psbb-yang-dibuat-untuk-cegah-penyebaran-corona-di-indonesiaeMXT

Ebrahim, S. H., Ahmed, Q. A., Gozzer, E., Schlagenhauf, P., \& Memish, Z. A. (2020). Covid-19 and community mitigation strategies in a pandemic. BMJ, m1066. https://doi.org/10.1136/bmj.m1066

Ering, M. (2020). Gereja Rumah di Masa Pandemi Covid-19: Manajemen Resiko dan Mitigasi Bencana Non Alam. Jurnal Sosiologi Agama, 1(1), 1-14.

Everett, J. A. C., Colombatto, C., Chituc, V., Brady, W. J., \& Crockett, M. (2020). The effectiveness of moral messages on public health behavioral intentions during the COVID-19 pandemic. https://doi.org/10.31234/osf.io/9yqs8

Fardin, M. A. (2020). COVID-19 Epidemic and Spirituality: A Review of the Benefits of Religion in Times of Crisis. Jundishapur Journal of Chronic Disease Care, 9(2). https://doi.org/10.5812/jjcdc.104260

Ghofur, A., \& Subahri, B. (2020). Konstruksi Sosial Keagamaan Masyarakat Pada Masa Pandemi Covid-19. Dakwatuna: Jurnal Dakwah dan Komunikasi Islam, 6(2), 281-301.

Ghosh, K., Amin, S. A., Gayen, S., \& Jha, T. (2021). Chemical-informatics approach to COVID-19 drug discovery: Exploration of important fragments and data mining based prediction of some hits from natural origins as main protease (Mpro) inhibitors. Journal of Molecular Structure, 1224, 129026. https://doi.org/10.1016/j.molstruc.2020.129026

Hadi, S. (2020). Pengurangan Risiko Pandemi Covid-19 Secara Partisipatif: Suatu Tinjauan Ketahanan Nasional terhadap Bencana. Jurnal Perencanaan Pembangunan: The Indonesian Journal of Development Planning, 4(2), 177190. https://doi.org/10.36574/jpp.v4i2.109

Hutahaean, H. (2020). Pelayan Tuhan di Gereja dan Masyarakat. Banggai: Pustaka Star's Lub.

Indriya, I. (2020). Konsep tafakkur dalam alquran dalam menyikapi coronavirus COVID-19. SALAM: Jurnal Sosial dan Budaya Syar-i, 7(3), 211-216.

Iqbal, Q., Tareen, A. M., \& Saleem, F. (2020). Religious cliché and COVID-19 management: a barrier for physicians. British Journal of General Practice, 70(695), 278.1-278. https://doi.org/10.3399/bjgp20X709961

Juntra, L., Program, U., Gizi, S., Kemenkes, P., Jalan, K., \& Tallo -Kupang, P. A. (2020). Gaya Hidup Mayarakat 
Nusa Tenggara Timur Dalam Menghadapi Pandemi Corona Virus Disease 19 (Covid-19). An-Nadaa: Jurnal Kesehatan Masyarakat, 7(1), 34-40.

Kowalczyk, O., Roszkowski, K., Montane, X., Pawliszak, W., Tylkowski, B., \& Bajek, A. (2020). Religion and Faith Perception in a Pandemic of COVID-19. Journal of Religion and Health, 59(6), 2671-2677. https://doi.org/10.1007/s10943-020-01088-3

Kurahman, T. (2018). Nilai, Peran, serta Fungsi Shalat dan Masjid dalam Menyikapi Problematika Masyarakat Modern. Jurnal Ilmiah Mahasiswa Raushan Fikr, 7(1), 109-129.

Lake, M. A. (2020). What we know so far: COVID-19 current clinical knowledge and research. Clinical Medicine, 20(2), 124-127. https://doi.org/10.7861/clinmed.2019-coron

Lillard, D. R. (2020). A Cross-National Design to Estimate Effects of COVID-Induced Non-Pharmacological Interventions. Survey Research Methods, 14(2), 211-216. https://doi.org/10.18148/srm/2020.v14i2.7766

Loey, M., Manogaran, G., Taha, M. H. N., \& Khalifa, N. E. M. (2021). A hybrid deep transfer learning model with machine learning methods for face mask detection in the era of the COVID-19 pandemic. Measurement, 167, 108288. https://doi.org/10.1016/j.measurement.2020.108288

Maliki, M. (2020). Covid-19, Agama, dan Sains. MAARIF, 15(1), 60-92. https://doi.org/10.47651/mrf.v15i1.77

Mardhia, D., Kautsari, N., Syaputra, L. I., Ramdhani, W., \& Rasiardhi, C. O. (2020). Penerapan Protokol Kesehatan dan Dampak Covid-19 Terhadap Harga Komoditas Perikanan dan Aktivitas Penangkapan. Indonesian Journal of Applied Science and Technology, 1(2), 80-87.

Marpaung, E. W. B. H., Adrian, L., \& Putri, S. A. (2020). Pandemi COVID-19: Dampak Sosial-Ekonomi, Tantangan, dan Potensi Solusi. Demografi Sosial. https://doi.org/10.13140/RG.2.2.35252.68483

Maulana, A. M. R. (2020). Pandemi dalam Worldview Islam; Dari Konsepsi ke Konspirasi. Tribakti: Jurnal Pemikiran Keislaman, 31(2), 307-323. https://doi.org/10.33367/tribakti.v31i2.1232

Mbanuzuru, A. V., Okoro, C. C., Mbanuzuru, C. M., \& Ibeh, C. C. (2021). Call for proper documentation of COVID19 deaths in poor resource setting: a necessity for management of future occurrences. Expert Review of Antiinfective Therapy, 19(1), 17-21. https://doi.org/10.1080/14787210.2020.1801418

Molteni, F., Ladini, R., Biolcati, F., Chiesi, A. M., Dotti Sani, G. M., Guglielmi, S., .. Vezzoni, C. (2021). Searching for comfort in religion: insecurity and religious behaviour during the COVID-19 pandemic in Italy. European Societies, 23(sup1), S704-S720. https://doi.org/10.1080/14616696.2020.1836383

Moulahoum, H., Ghorbanizamani, F., Zihnioglu, F., Turhan, K., \& Timur, S. (2021). How should diagnostic kits development adapt quickly in COVID 19-like pandemic models? Pros and cons of sensory platforms used in COVID-19 sensing. Talanta, 222, 121534. https://doi.org/10.1016/j.talanta.2020.121534

Nurul Aula, S. K. (2020). Peran Tokoh Agama Dalam Memutus Rantai Pandemi Covid-19 Di Media Online Indonesia. Living Islam: Journal of Islamic Discourses, 3(1), 125. https://doi.org/10.14421/lijid.v3i1.2224

Pabbajah, M., Said, N. M., Faisal, Pabbajah, T. H., Jubba, H., \& Juhansar. (2020). Deauthorization of the Religious Leader Role in Countering Covid-19: Perceptions and Responses of Muslim Societies on the Ulama's Policies in Indonesia. International Journal of Criminology and Sociology, 9(1), 263-273.

Pamungkas, J., \& Anggana, B. D. (2019). Relasi Sosial Masjid Baitul Falah dengan Gereja Bethel Indonesia (GBI) Rock di Surabaya. Empirisma: Jurnal Pemikiran dan Kebudayaan Islam, 28(1), 49-61.

Qodir, Z., Effendi, G. N., Jubba, H., Nurmandi, A., \& Hidayati, M. (2020). Covid-19 and Chaos In Indonesia SocialPolitical Responsibilities. Journal of Talent Development and Excellence, 12(1), 4629-4642.

Regus, M. (2021). Regulating religion in a time of COVID-19 pandemic in Indonesia: context, dynamics, and implication. International Journal of Sociology and Social Policy, ahead-of-p(ahead-of-print). https://doi.org/10.1108/IJSSP-07-2020-0321

Ridlo, I. A. (2020). Pandemi COVID-19 dan Tantangan Kebijakan Kesehatan Mental di Indonesia. INSAN Jurnal Psikologi dan Kesehatan Mental, 5(2), 162. https://doi.org/10.20473/jpkm.V5I22020.162-171

Siregar, A. K., \& Jubba, H. (2020). Dampak Wabah Corona Virus Desease terhadap Budaya Ibadah Umat Muslim dan Kebijakan Pemerintah. Poros Onim: Journal of Social Religious, 1(2), 151-163.

Siringoringo, M. (2016). Pertumbuhan Gereja dari Persfektif Kitab Kisah Para Rasul. Prosiding Sejarah dan Pertumbuhan Gereja, 98-104.

Telaumbanua, D. (2020). Urgensi Pembentukan Aturan Terkait Pencegahan Covid-19 di Indonesia. QALAMUNA: Jurnal Pendidikan, Sosial, dan Agama, 12(01), 59-70. https://doi.org/10.37680/qalamuna.v12i01.290

Wibisono, M. Y., Truna, D. S., \& Rahman, M. T. (2021). Turning religion from cause to reducer of panic during the COVID-19 pandemic. HTS Teologiese Studies / Theological Studies, 77(4), 1-8. https://doi.org/10.4102/hts.v77i4.6366

Wong, M. D., Thai, T., Li, Y., \& Liu, H. (2020). The role of chest computed tomography in the management of COVID-19: A review of results and recommendations. Experimental Biology and Medicine, 245(13), 1096-1103. https://doi.org/10.1177/1535370220938315 
Yanti, F. (2019). Komunikasi social dalam membangun komunikasi umat: Kajian makna tradisi Ied (lebaran) pada masyarakat Muslim di Bandar Lampung. Komunika, 2(1), 1-16.

Yusup, D. K., Badriyah, M., Suyandi, D., \& Asih, V. S. (2020). Pengaruh bencana Covid-19, pembatasan sosial, dan sistem pemasaran online terhadap perubahan perilaku konsumen dalam membeli produk retail.

Zahratunnisa, Z. (2020). Peran Ulama Dalam Mitigasi Pandemi Covid-19. 'ADALAH, 4(1), 259-269.

(C) 2021 by the authors. Submitted for possible open access publication under the terms and conditions of the Creative Commons Attribution (CC BY SA) license (https://creativecommons.org/licenses/by-sa/3.0/). 